\title{
Agter die syfers is gelowiges, gemeentes en die kerk, 'n prakties teologiese refleksie oor lidmaatskap
}

\begin{tabular}{|c|c|}
\hline $\begin{array}{l}\text { Author: } \\
\text { W.J. (Kobus) So }\end{array}$ & choeman ${ }^{1}$ \\
\hline $\begin{array}{l}\text { Affiliation: } \\
{ }^{1} \text { Department } \\
\text { Theology, Facu } \\
\text { Theology, Uni } \\
\text { Free State, Sou }\end{array}$ & $\begin{array}{l}\text { f Practical } \\
\text { ulty of } \\
\text { versity of the } \\
\text { uth Africa }\end{array}$ \\
\hline $\begin{array}{l}\text { Note: } \\
\text { A part of this } \\
\text { was presented } \\
\text { Lentekonferen } \\
\text { Sept. 2013). Tr } \\
\text { paper was 'Agt } \\
\text { gemeentes en }\end{array}$ & $\begin{array}{l}\text { article } \\
\text { at the } \\
\text { sie (17-19 } \\
\text { he titel of the } \\
\text { ter die syfers is } \\
\text { die kerk'. }\end{array}$ \\
\hline $\begin{array}{l}\text { Corresponden } \\
\text { Kobus Schoem }\end{array}$ & $\begin{array}{l}\text { Ice to: } \\
\text { tan }\end{array}$ \\
\hline $\begin{array}{l}\text { Email: } \\
\text { schoemanw@ }\end{array}$ & ufs.ac.za \\
\hline $\begin{array}{l}\text { Postal address } \\
\text { Posbus Box } 28 \\
9301 \text {, Bloemfo }\end{array}$ & $\begin{array}{l}861 \text {, Danhof } \\
\text { ontein }\end{array}$ \\
\hline $\begin{array}{l}\text { Dates: } \\
\text { Received: } 07 \mathrm{~A} \\
\text { Accepted: } 03 \\
\text { Published: } 20\end{array}$ & $\begin{array}{l}\text { Apr. } 2014 \\
\text { Aug. } 2014 \\
\text { Nov. } 2014\end{array}$ \\
\hline $\begin{array}{l}\text { How to cite th } \\
\text { Schoeman, W. } \\
\text { die syfers is ge } \\
\text { gemeentes en } \\
\text { 'n praktiese te } \\
\text { refleksie oor li } \\
\text { HTS Teologiese } \\
\text { Theological St } \\
\text { Art. \#2677, } 10 \\
\text { dx.doi.org/10. } \\
\text { v70i1.2677 }\end{array}$ & $\begin{array}{l}\text { is article: } \\
\text { J., 2014, 'Agter } \\
\text { lowiges, } \\
\text { die kerk, } \\
\text { ologiese } \\
\text { dmaatskap', } \\
\text { e Studies/ } \\
\text { udies 70(1), } \\
\text { pages. http:// } \\
\text { 4102/hts. }\end{array}$ \\
\hline $\begin{array}{l}\text { Copyright: } \\
\text { (C) 2014. The A } \\
\text { Licensee: AOS } \\
\text { OpenJournals. } \\
\text { is licensed und } \\
\text { Creative Comn } \\
\text { Attribution Lic }\end{array}$ & $\begin{array}{l}\text { luthors. } \\
\text { IS } \\
\text { This work } \\
\text { der the } \\
\text { nons } \\
\text { ense. }\end{array}$ \\
\hline Read online: & \\
\hline 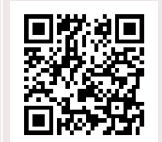 & $\begin{array}{l}\text { Scan this QR } \\
\text { code with your } \\
\text { smart phone or } \\
\text { mobile device } \\
\text { to read online. }\end{array}$ \\
\hline
\end{tabular}

Behind the numbers are believers, congregations and the church, a practical theological reflection on membership. Churches, especially mainline churches, reported the past few years a decline in their membership numbers. This trend of declining membership deserves attention and asks for a practical theological reflection. Behind the declining statistics are believers, congregations and churches that should be part of a broader reflection. Membership not only describes a static and geographic relationship, it can also be described as dynamic and fluid. The purpose of this article is to discuss this declining trend of church membership from a practical theological perspective. This phenomenon is discussed for the church in general and then the specific situation of the Dutch Reformed Church is described in more depth. The latest Church mirror data (an empirical survey in the DRC) is used as a quantitative lens. Against this background it is clear that the relationship between member and congregation exists within a dynamic and changing context, which can no longer be described in simplistic terms. Membership should be seen as a fluid and variable concept that describes the relationship with the congregation. The challenge is to develop a new ecclesiology with new terms and metaphors to describe this relationship.

\section{Inleiding}

Kerke, veral hoofstroom kerke, rapporteer die afgelope aantal jare 'n daling inlidmaatgetalle. Hierdie tendens is nie uniek aan Suid-Afrika nie, dit kom ook in Europa (Davie 2007:272) en in die Verenigde State van Amerika (Bruce et al. 2006:111; Roozen 2008:5) voor. Die gevolg van die dalende lidmaatgetalle is dat sommige gemeentes moet toemaak of met ander moet saamsmelt om te oorleef. In Suid-Afrikaanse konteks word veral die hoofstroom Afrikaanse kerke akuut geraak. 'n Denominasie wat 'n paar duisend lidmate per jaar verloor, kan binne enkele jare ernstige probleme ondervind en selfs binne 'n dekade of twee verdwyn. Hierdie tendens van dalende lidmaatskappe verdien aandag en vra 'n prakties-teologiese refleksie.

Kerke en gemeentes bevind hulleself binne 'n dinamies-veranderende omgewing, wat ontleed en beskryf moet word. So 'n ontleding en beskrywing vorm deel van die prakties-teologiese studieveld. Die kartering van hierdie dinamika sluit die geloofsinteraksie tussen individue en die geloofsgemeenskap in (Ganzevoort 2009:7).

Lidmaatskap word oor die algemeen as 'n gelowinge se lewenslange geloofsverbintenis aan 'n gemeente verstaan. Die verbintenis begin gewoonlik by dooplidmaatskap wat op ongeveer sestienjarige ouderdom op 'n openbare geloofsbelydenis uitloop. Die kritiese vraag wat in die hedendaagse samelewing gevra behoort te word, is of hierdie uitdrukking van 'n geloofsverbintenis nog steeds so in die praktyk werk en so verstaan word (kyk Heitink 2008:160-161). Die daling in lidmaatgetalle binne die hoofstroom Afrikaanse kerke kan die gevolg van veroudering en emigrasiepatrone wees, maar dit kan ook 'n gevolg van 'n veranderende samelewing en konteks impliseer.

Die veranderende samelewing en konteks daag gemeentes en die kerk tans tot 'n herbesinning van lidmaatskap uit. Hierdie aspekte word onder meer in hierdie artikel aan orde gebring. Die gevaar bestaan dat daar slegs vanuit 'n statistiese perspektief na die statistieke oor die wisseling in lidmaatskap gekyk sal word en dat die redes en motiverings agter die verskynsel nie geïdentifiseer sal word nie. Agter die dalende statistieke is gelowiges, gemeentes en kerke wat deel van 'n breër besinning behoort te vorm. Die begrip lidmaatskap kan nie bloot as 'n statiese, geografies-gedefinieerde verhouding beskryf word nie, dit behoort ook as 'n dinamiese en vloeibare verhouding beskryf te word.

Die doel van die artikel is om vanuit 'n prakties-teologiese perspektief na die tendens van dalende kerklike lidmaatskap te kyk. Die eerste prakties-teologiese oorweging is om 'n empiriese analise van die tendens te maak (Heitink 1993:159-162; Osmer 2008:37-39). Die 
verskynsel word binne 'n breë Suid-Afrikaanse kerklike raamwerk geplaas, waarna die spesifieke fokus op die situasie binne die NG Kerk geplaas word. Die empiriese beskrywing van die tendense sal met sekere teoretiese riglyne opgevolg word. Die riglyne kan moontlik bydra om lidmaatskap binne 'n nuwe en veranderende konteks te beskryf, verstaan en bespreek. Hierdie tweede praktiesteologiese oorweging (kyk hofie "n Raamwerk vir nuwe of veranderende verstaan van lidmaatskap') bied 'n teoretiese interpretasie van (Osmer 2008:82-84) of 'n teologiese refleksie (Heitink 2008:25) op lidmaatskap.

\section{Godsdienstige lidmaatskap en affiliasie in Suid-Afrika}

Lidmaatskap dui op die betrokkenheid van mense by 'n bepaalde godsdienstige organisasie, soos denominasies en gemeentes. Op kwantitatiewe vlak word lidmaatskap aan statistieke van staatsensusse, verslae van denominasies en lidmaatskapregisters of databasisse van gemeentes gemeet. In hierdie afdeling word eerstens na die breër Suid-Afrikaanse prentjie gekyk en daarna word die fokus op die lidmaatskap van enkele van die hoofstroom Afrikaanse gereformeerde kerke geplaas.

\section{Godsdienstige affiliasie in Suid-Afrika}

'n Staatsensus kan 'n aanduiding van godsdienstige lidmaatskap in 'n land gee. 'n Ondersoek na godsdienstige affiliasie in Suid-Afrika is die laaste keer tydens die 2001-staatssensus gedoen. Hoewel die 2001-sensus verskeie leemtes gehad het en probleme opgelewer het om betrokkenheid by godsdiens en denominasies te bepaal (kyk Hendriks \& Erasmus 2005 vir 'n volledige bespreking hiervan), kan die sensusdata wel gebruik word om sekere algemene tendense uit te lig.

Volgens Erasmus en Hendriks (2005) het die Christelike geloof in Suid-Afrika eers gegroei (1911-1980), daarna het dit afgeneem (1991-1996) en waarskynlik weer teen 2001 effens toegeneem. Die groeipatrone hou met die diverse samestelling van die Suid-Afrikaanse bevolking verband. Hierdie tendense ten opsigte van die groeikoers word in die eerste plek deur die groei in Christelike affiliasie onder die swart bevolking en die afname in Christene in beide die Wit en Bruin bevolkingsgroepe verklaar. Die daling in Christelike affiliasie in die geval van laasgenoemde twee bevolkingsgroepe is as gevolg van '... a rapidly declining birth rate and a large number of especially younger White people who emigrated or are working overseas' (Erasmus \& Hendriks 2005:102). Daar is dus wisselende Christelike affiliasiepatrone binne die verskillende bevolkingsgroepe in Suid-Afrika. Die 2001-sensusdata oor godsdienstige affiliasie in Suid-Afrika word in Tabel 1 gebied.

Volgens die 2001-sensusdate het 79.79\% van die bevolking aan'n Christelike denominasie behoort (vergelyk Tabel1). Die grootste gedeelte van die Suid-Afrikaanse bevolking behoort aan 'n Afrika-onafhanklike of geïnisieerde kerk (40.82\% van Christene). Behalwe vir persone wat aan 'n 'ander' Christelike denominasie behoort, is daar ' $n$ wye verspreiding onder die verskillende denominasies: 'n beduidende hoeveelheid Christene is lidmate van Metodiste, Gereformeerde en Rooms Katolieke denominasies. Lidmaatskap verander egter met verloop van tyd.

'n Belangrike tendens is die afname binne die Wit bevolkingsgroep van lidmate wat aan 'n Gereformeerde denominasie behoort. Dit word deur Erasmus en Hendriks (2005:105) bevestig '... the Reformed Churches, which dominated the market (before 1991 50\% plus), are beginning to lose their market share. It dropped to $42.8 \%$ in 2001.' Die moontlikheid bestaan dat hierdie tendens na 2001 voortgesit sou word.

Dit is moeilik om te bepaal in watter mate die situasie sedert 2001 verander het. Die 2011-staatsensus het ongelukkig geen ondersoek oor godsdienstige lidmaatskap gedoen nie. Die Pew Forum on Religion and public life het egter in April 2010 omvattende verslag oor 'Tolerance and tension: Islam

TABEL 1: Sensus 2001.

\begin{tabular}{|c|c|c|c|}
\hline Denominasie & Totaal & Christelik (\%) & Totaal (\%) \\
\hline Geformeerd & 3232194 & 9.04 & 7.21 \\
\hline Anglikaan & 1722076 & 4.82 & 3.84 \\
\hline Metodis & 3305404 & 9.24 & 7.37 \\
\hline Luthers & 1130986 & 3.16 & 2.52 \\
\hline Presbiteriaan, Baptis & 1687668 & 4.72 & 3.77 \\
\hline Rooms Katoliek & 3181336 & 8.90 & 7.10 \\
\hline Pentakostal, Charismaties & 2625830 & 7.34 & 5.86 \\
\hline Afrika onafhanklik & 14598922 & 40.82 & 32.57 \\
\hline Ander Christelik & 4275942 & 11.96 & 9.54 \\
\hline Totaal Christelik & 35760358 & 100.00 & 79.79 \\
\hline Joodse geloof & 75555 & - & 0.17 \\
\hline Hindoeïsme & 551669 & - & 1.23 \\
\hline Moslem geloof & 654064 & - & 1.46 \\
\hline Oosterse gelowe & 7395 & - & 0.02 \\
\hline Totaal ander gelowe & 1706547 & - & 3.81 \\
\hline Geen godsdiens/weier/Nie gespesifiseer & 7352875 & - & 16.41 \\
\hline Totaal Suid-Afrikaanse bevolking & 44819780 & - & 100.00 \\
\hline
\end{tabular}


and Christianity in sub-Saharan Africa' gelewer. Gegewens in hierdie verslag kan verwerk word om 'n beeld van die godsdienstige landskap in Suid-Afrika sedert 2001 te vorm. Die ondersoek het getoon dat $87 \%$ van die Suid-Afrikaanse bevolking as Christelik geklassifiseer kan word (Lugo \& Cooperman 2010:20-23). Wat Christelike affiliasie betref, word $84 \%$ van die Christene as protestants beskryf. Dit kan egter bevraagteken word of die Afrika-geïnisieerde kerke (35\% van die protestantse Christene volgens die verslag) as deel van die protestantse tradisie beskou behoort te word. Die verslag wys daarop dat die Christelike aandeel binne die totale Suid-Afrikaanse bevolking toegeneem het.

Godsdienstige affiliasie gaan nie net oor nominale lidmaatskap (die aantal lidmate) nie, maar ook oor toewyding. In 2012 verskyn ' $n$ verslag van WIN-Gallup International oor godsdienstigheid in die wêreld. Respondente is versoek om die volgende vraag te beantwoord: 'Irrespective of whether you attend a place of worship or not, would you say you are a religious person, not a religious persons or a convinced atheist?' Die bevinding oor Suid-Afrika is dat godsdienstigheid afgeneem het van 83\% in 2005 tot $64 \%$ in 2012 (Shahid \& Zuettel 2012). Die verband tussen godsdienstigheid en nominale lidmaatskap is moeilik bepaalbaar. Die 2010-Pew verslag toon die volgende in terme van die toewyding van die lidmate (Lugo \& Cooperman 2010):

- $74 \%$ van die Suid-Afrikaanse bevolking beskou godsdiens as baie belangrik in hulle lewens (bl. 3)

- $60 \%$ van Suid-Afrikaanse Christene woon weekliks een of meer eredienste of byeenkomste by (bl. 27)

- In Suid-Afrika word 89\% van die bevolking binne die Christelike godsdiens grootgemaak, terwyl $87 \%$ hulself (in 2010) as Christene beskou. Hierdie 2\%-afname (bl. 12) dui op 'n verskuiwing weg van die Christelike godsdiens.

Die kartering van die Suid-Afrikaanse godsdienstige landskap is nie maklik nie. Die drie verslae (Staatsensus van 2001, Pew-verslag van 2010 en die Win-Gallup-verslag van 2012) belig verskillende aspekte van die godsdienstige landskap, daarom is dit 'n komplekse prentjie wat vanuit verskeie hoeke beskryf kan word. Alhoewel die Christelike godsdiens as die meerderheidsgodsdiens in Suid-Afrika geïdentifiseer word, is dit belangrik om aan te toon dat wisselende vlakke van toewyding en assosiasie binne die breër Suid-Afrikaanse geloofsgemeenskap heers.

\section{Lidmaatskap binne die Afrikaanse hoofstroom kerke}

Die fokus verskuif nou na die plek van Afrikaanse hoofstroom kerke binne die Suid-Afrikaanse godsdienstige landskap. Die drie grootste Afrikaanse kerke, naamlik die Nederduitse
Gereformeerde Kerk (NG Kerk), die Nederduitsch Hervormde Kerk van Afrika (NHKA) en die Gereformeerde Kerke in SuidAfrika (GKSA) word in hierdie verband bespreek.

Dreyer (2003:1052) maak die volgende algemene opmerking: 'Die Gereformeerde groepe se markaandeel in Suid- Afrika onder die Christene het gedaal van 33\% in 1911 tot $16 \%$ in 1991'. Die lidmaatgetalle van die drie denominasies word in Tabel 2 weergegee. (Die situasie binne die NG Kerk word volledig in die volgende afdeling bespreek.).

Daar is van amptelike bronne, soos jaarboeke en sinodale verslae gebruik gemaak om die tabel saam te stel (kyk o.a. Handelinge van die GKSA 2012 en Notule van die Algemene Kerkvergadering van NHKA 2010). Die totale lidmaattal van die NHKA het tussen 1972 en 2000 met byna 21000 gedaal, terwyl die aantal dooplidmate tydens hierdie tydperk bykans gehalveer het (kyk Tabel 2). Dreyer (2003:1054) bied die volgende verklarings vir die daling in die getalle:

- 'n daling in die blanke bevolking, onder andere weens emigrasie

- die daling in die geboortekoers, die tradisionele bron van lidmate, wat dan ook tot ' $n$ afname in belydende lidmate bydra

- perforering van gemeentegrense, wat veroorsaak dat 'n beduidende aantal lidmate by ander gemeentes inskakel, maar nie formeel deur die ander gemeente ingereken word nie.

Die dalende tendens duur na 2000 voort en die NHKA verloor gedurende die tydperk tussen 2000 tot 2010 bykans 60000 lidmate, waarvan die aantal dooplidmate die grootste daling toon.

Die GKSA ervaar ook 'n daling in lidmaattalle (Tabel 2). Die lidmaattalle het tussen 1990 en 2010 met meer as 30\% gedaal en die aantal dooplidmate het gedurende die tydperk met meer as 65\% gedaal. De Klerk en Van Helden (2011) noem dit 'kerkkrimping'. Hulle voer aan dat die ' ... sameloop van historiese en hedendaagse meetbare en onmeetbare faktore binne en buite die gelowiges, te midde van die onstuitbare voortstuwende beweeglikheid van die Christendom die krimping van die kerk veroorsaak' (De Klerk \& Van Helden 2011). Hierdie outeurs het ook tendense soos sekularisasie, ontkerstening, materialisme, individualisme en die verandering binne 'n postmoderne samelewing uitgelig. In die lig van hierdie tendense besluit die Algemene Sinode van 2012 om ondersoek in te stel om 'n omkeerstrategie vir die kerk te ontwerp (Handelinge GKSA 2012:509-511). Die tradisionele en gevestigde patrone van betrokkenheid by denominasies is besig om binne die Afrikaanse hoofstroom kerke te verander. In dié verband noem Dreyer (2003):

TABEL 2: Lidmaatskap binne die Afrikaanse hoofstroom kerke.

\begin{tabular}{|c|c|c|c|c|c|c|c|c|c|}
\hline \multirow[t]{2}{*}{ Jaar } & \multicolumn{3}{|c|}{ Hervormde Kerk } & \multicolumn{3}{|c|}{ Gereformeerde Kerke } & \multicolumn{3}{|c|}{ Nederduits Gereformeerde Kerk } \\
\hline & Totaal & Bely & Doop & Totaal & Bely & Doop & Totaal & Bely & Doop \\
\hline 1972 & 183573 & 113498 & 70075 & 104000 & 64000 & 40000 & 1601602 & 826565 & 775037 \\
\hline 1990 & 192541 & 132483 & 60058 & 113981 & 78945 & 35036 & 1340065 & 920274 & 419791 \\
\hline 2000 & 162526 & 120937 & 41589 & 101193 & 74952 & 26241 & 1269874 & 941037 & 328837 \\
\hline 2010 & 105000 & 81147 & 23853 & 79841 & 63951 & 15890 & 1089055 & 840610 & 248445 \\
\hline
\end{tabular}


Die tanende markaandeel in die hoofstroomkerke word hoofsaaklik toegeskryf aan die feit dat diegene met geld en mag se behoefte aan die kerk afneem, terwyl diegene daarsonder nie maklik 'n tuiste vind in die hoofstroom kerke met hiërargiese strukture en van-bo-na-onder styl van kerkwees nie. (bl. 1052)

Die NG Kerk kan hierdie verskuiwings nie ontsnap nie, daarom vereis hierdie toedrag van sake nadenke oor lidmaatskap en 'n kritiese refleksie. Vervolgens word die verskuiwings in die lidmaatgetalle en affiliasie van die NG Kerk in meer diepte bespreek.

\section{'n Empiriese beskrywing van lidmaatskap in die NG Kerk}

Die bespreking van lidmaatskap in die NG Kerk gaan hoofsaaklik vanuit 'n kwantitatiewe perspektief gedoen word. Die resultate van die Kerkspieëlondersoeke word gebruik en daarom word die metodologie, wat in hierdie ondersoeke gebruik is, eers bespreek. Daarna word aan drie aspekte aandag gegee, naamlik:

- 'n beskrywing van lidmaatgetalle van die kerk

- die plek en rol van die gemeente in die verstaan van lidmaatskap

- enkele aspekte van lidmate se menings oor hulle verbintenis aan gemeentes.

\section{Die metodologie van die Kerkspieël-ondersoeke}

Kerkspieël is 'n omvattende opname wat sedert 1981 vierjaarliks in die NG Kerk, in opdrag van die Algemene Sinode, gedoen word (Vir 'n meer omvattende beskrywing hiervan, sien Schoeman [2011]). Vir die doel van hierdie artikel word data van twee opnames, naamlik 2006 en 2010 gebruik ten opsigte van die gemeente-opname en die erediensbywoner opname.

In die geval van die gemeente-opname word 'n omvattende vraelys aan elke gemeente in die NG Kerk gestuur. Die vraelys, wat ondersoek instel na verskeie aspekte van die gemeente en haar funksionering, word deur die leierskap van die gemeente ingevul. Al die voltooide vraelyste word verwerk. Vir analiseringsdoeleiendes van die gemeentelike data word gewigte vir elke gemeente bereken, sodat afleidings oor die kerk as geheel gemaak kan word. In 2006 is 602 van die 1176 gemeentevraelyste terugontvang ('n responskoers van 51.2\%). In 2010 word die gemeentevraelyste na 1146 gemeentes gestuur en 671 (58.6\%) word verwerk.

Die erediensbywoner-vraelys bied aan gemeentelede, wat op 'n bepaalde Sondag 'n erediens bygewoon het, die geleentheid om oor verskeie sake rakende die gemeente menings en houdings weer te gee. Die vraelys wat gebruik word, is die 'Church Life Surveys' (CLS). Hierdie vraeslys is in 1991 in Australië ontwerp en 6700 gemeentes van 18 denominasies het die eerste CLS-vraelys voltooi.

Daarna is die vraelys ook in Nieu-Seeland, Groot Brittanje en die VSA gebruik. In 2001 neem ongeveer 1.2 miljoen erediensbywoners in die vier lande aan die International Congregational Church Life Survey deel (kyk Woolever \& Bruce 2004). Die erediensbywoner-opname, wat deel van die Kerkspieël ondersoek vorm, is aan die hand van dié CLS vraelys ontwikkel en in 2001 vir die eerste keer in die NG Kerk gebruik. Die vraelyste word op 'n spesifieke Sondag tydens ' $n$ erediens deur al die erediensbywoners ouer as 15 jaar voltooi. In 2006 word 'n ewekansige steekproef van $10 \%$ uit die 1176 NG gemeentes getrek en hierdie 118 gemeentes is versoek om die vraelys in Augustus 2006 tydens 'n erediens te voltooi. Vyf en negentig gemeentes het die vraelys voltooi (responskoers: 81\%) en 12522 voltooide vraelyste is terugbesorg. Die opname is in 2010 herhaal en 'n soortgelyke steekproef as in 2006 word getrek. Die steekproefbevolking was 115 gemeentes, waarvan 85 (responskoers: 75\%) gemeentes die vraelyste voltooi en 12286 vraelyste terugbesorg is (kyk Tabel 7 - Tabel 13).

\section{Lidmaatskap in die NG kerk - die groter prentjie}

Die NG Kerk, net soos in die geval van ander hoofstroom Afrikaanse kerke, ervaar 'n daling in lidmaatgetalle tussen 1972 en 2010 kyk Tabel 2). Die totale aantal belydende lidmate wissel tussen 820000 in 1972 en 840000 in 2010. Die groot wisseling in lidmaattalle in die NG Kerk was ten opsigte van die aantal dooplidmate Die aantal dooplidmate het deurgaans gedaal, vanaf 775000 in 1972 tot 248000 in 2010. Die NG Kerk het dus teen 2010 ongeveer 68\% minder dooplidmate gehad as wat in 1972 die geval was. Die aantal dooplidmate van die NG Kerk het tussen 1990 en 2010 met ongeveer 170000 gedaal. Dit wil voorkom asof die daling in dooplidmate verhoudingsgewys minder is as in die geval van die NHKA en GKSA is aangesien beide ' $n$ daling van ongeveer $70 \%$ ervaar het. Die verhouding van belydende tot dooplidmate het ook met verloop van tyd wesenlik verander (kyk Tabel 3).

Ongeveer die helfte van die lidmate van die NG Kerk (48\%) was in 1972 dooplidmate. Die verhouding het met verloop van tyd verander. Teen die tagtiger jare was ongeveer 'n derde $(35 \%$ - 31\%) van die lidmate dooplidmate en teen 2010 het die verhouding na minder as 'n kwart (23\%) van die lidmate verlaag. Soos in die geval van ander Afrikaanse hoofstroom kerke reflekteer die NG Kerk die profiel van 'n ouer wordende samelewing. Dié tendens kan met die veroudering van die blanke bevolking saamgelees word.

TABEL 3: Samestelling van die lidmaatgetalle (uitgedruk as' $n$ persentasie).

\begin{tabular}{lcccccccccc}
\hline Tipe lidmaat & \multicolumn{10}{c}{ Jaar } \\
\cline { 2 - 10 } & $\mathbf{1 9 7 2}$ & $\mathbf{1 9 8 1}$ & $\mathbf{1 9 8 5}$ & $\mathbf{1 9 8 9}$ & $\mathbf{1 9 9 3}$ & $\mathbf{1 9 9 6}$ & $\mathbf{2 0 0 0}$ & $\mathbf{2 0 0 4}$ \\
\hline Belydend & $52 \%$ & $65 \%$ & $66 \%$ & $69 \%$ & $71 \%$ & $71 \%$ & $\mathbf{2 0 0 6}$ & $74 \%$ & $76 \%$ \\
Doop & $48 \%$ & $35 \%$ & $34 \%$ & $31 \%$ & $29 \%$ & $29 \%$ & $26 \%$ & $24 \%$ & $23 \%$ & $23 \%$ \\
Senior & - & - & - & - & - & - & - & - & $22 \%$ & $23 \%$ \\
\hline
\end{tabular}


Die vraag hoeveel lidmate ouer as 60 jaar is, word vir die eerste keer in 2006 gestel. In 2010 is meer lidmate ouer as 60 jaar as wat daar dooplidmate in die kerk was. Die tendens bevestig die veroudering wat binne die kerk se lidmaatsamestelling plaasvind.

Die lidmaatgetalle van die NG Kerk daal na 2010 verder. Die Jaarboek van die NG Kerk wys daarop dat die kerk 'n verlies van net minder as 50000 doop- en belydenislidmate tussen 2011 en 2013 gely het (Tabel 4).

Die tendens dui daarop dat 'n afname in die aantal gemeentes kan volg en daarom is die kritiese vraag wat gevra kan word wat die uiteinde van die tendens sal wees. Die aanname word soms gemaak dat die kerk kan verdwyn (kyk bv. Rapport 19 Februarie 2012). Die argument is waarskynlik meer kompleks as wat 'n enkele liniêre voorspelling moontlik kan maak. Die latere bespreking rondom die definiëring van lidmaatskap behoort hierdie stelling te steun.

Emigrasiepatrone het 'n bepaalde invloed op die lidmaatgetalle van 'n denominasie. Die stelling kan gemaak word dat emigrasie tot die dalende getalle kon bydra. Die invloed van emigrasie op die kerk se lidmaattal is moeilik bepaalbaar. Geen amptelike statistiese gegewens is beskikbaar nie en daar moet op ramings en skattings gesteun word. Daar word beraam dat ongeveer een miljoen witmense die land tussen 1995 en 2005 verlaat het (Rapport 24 September 2006). Uit die verslag van die South African Institute for Race Relations (2007) blyk dit dat die grootste gaping in die ouderdomspiramide van die wit bevolking by die ouderdomsgroep 20 tot 39 jaar is. Hierdie gaping hou ernstige implikasies vir die geboortekoers in en kan die afname in die wit kinders onder 10 jaar oud verklaar. As hierdie emigrasiesyfers as vertrekpunt aanvaar word, kan daar geredeneer word dat die kerk waarskynlik beter as verwagting gevaar het. Emigrasie bied verskeie verklarings vir die verskuiwings wat binne die bevolkingsamestelling aangetref word. Die veroudering van die bevolking speel 'n belangrike rol. Dit loop hand aan hand met 'n dalende geboortekoers en meer vrouens wat tot die arbeidsmark toetree en 'n hoër lewenstandaard handhaaf. Hierdie tendense veroorsaak wesenlike demografiese verandering binne die kerk.

TABEL 4: Nederduits Gereformeerde Kerk lidmate - Jaarboek statistiek.

\begin{tabular}{lcccc}
\hline Jaar & \multicolumn{4}{c}{ Lidmate } \\
\cline { 2 - 5 } & Belydend & Doop & Totaal & Verlies \\
\hline 2011 & 843414 & 231348 & 1074762 & - \\
2012 & 826839 & 227208 & 1054047 & 20715 \\
2013 & 803877 & 221102 & 1024979 & 29068 \\
\hline
\end{tabular}

TABLE 5: Gemeente rigting.

\begin{tabular}{lcc}
\hline Hoe sou u gemeente se huidige rigting tipeer & \multicolumn{2}{c}{ Jaar } \\
\cline { 2 - 3 } & $\mathbf{2 0 0 6 ( \% )}$ & $\mathbf{2 0 1 0}(\mathbf{\%})$ \\
\hline Krimpend en/of sterwend & 3.4 & 3.5 \\
Besig met instandhouding/oorlewing & 48.8 & 46.3 \\
Groeiend & 42.0 & 43.7 \\
Dinamies groeiend & 5.8 & 6.5 \\
\hline
\end{tabular}

Migrasie van lidmate tussen verskillende gemeentes, sonder om van geografiese adres te verander, vind ook binne die NG Kerk plaas. Kerkspieël 2000 het vir die eerste keer verslag gedoen oor gemeentelike migrasie. In 2000 was ongeveer 90000 lidmate buite die geografiese grense van hul gemeente woonagtig, wat op ongeveer $7 \%$ van die totale lidmaattal dui. Die tendens het toegeneem en teen 2010 was ongeveer 180000 lidmate (of 16\% van die lidmaattal) migreerders. Die omvang van hierdie vorm van gemeentelike migrasie is waarskynlik groter as wat die amptelike syfers aandui. Dit is moontlik dat meer as 'n derde van die lidmate buite die geografiese grense van hul gemeentes woon. Hierdie tendens raak die gesprek oor lidmaatskap en die verbintenis aan 'n gemeente wesenlik, want dit gaan nou oor meer as die geografiese adres van 'n lidmaat.

Die NG Kerk het eers in die negentiger jare van die vorige eeu 'n amptelike besluit oor lidmaatskap en gemeentegrense geneem. Die Algemene sinode van 1994 (Handelinge 1994:490, 491, 574) het onder andere die volgende besluite oor lidmaatskap en gemeentegrense geneem:

- Lidmaatskap van 'n gemeente (nie noodwendig die een binne wie se geografiese grense gewoon word nie) is verpligtend.

- By watter gemeente ingeskakel word, is die primêre verantwoordelikheid van die lidmaat.

- Gemeentes bly geografies ingedeel as die gebied waarvoor die gemeente die institusionele verantwoordelikheid aanvaar om die koninkryk van God op elke terrein te bevorder.

Uit die besluit is dit duidelik dat lidmaatskap die individu se verantwoordelikheid en besluit is. Die keusevryheid van lidmate plaas gemeentes in 'kompetisie' om die aandag en betrokkenheid van lidmate. Die band tussen geografiese adres en lidmaatskap word met die besluit amptelike opgehef en verander daarmee die definiëring en verstaan van lidmaatskap.

\section{Gemeentes se koers en lidmaatskap}

Diegesprek rondom diewisseling en daling van lidmaatgetalle behoort ook in 'n wyer gemeentelike raamwerk geplaas te word. Dit gaan oor meer as net die aantal lidmate, maar ook oor dit, wat in gemeentes met die lidmate gebeur. Die koers en rigting van 'n gemeente beïnvloed die lidmate van die gemeente. Die gemeente kan besig wees om te groei en uit te brei of dit kan onder druk wees om te oorleef. Dit hou verband met die aantal lidmate in 'n gemeente.

Byna die helfte van die gemeentes is besig met instandhouding (Tabel 5).

Tabel 5 toon dat' $n$ meerderheid van die gemeentes gedurende die 2006 tot 2010 tydperk met instandhouding besig gebly het of in ' $n$ stryd om oorlewing gewikkel was. Die verwagting is dat gemeentes wat met instandhouding besig is meestal na binne gerig is en 'n agenda volg wat op oorlewing fokus. Die behoud van lidmate is vir sulke gemeentes van kritiese 
belang. 'n Groeiende lidmaattal beteken 'n beter kans op oorlewing, terwyl 'n eensydige fokus op instandhouding die behoorlike funksionering van die gemeente ernstig inkort.

Gemeentes met 'n missionale verstaan behoort 'n groter openheid voor te staan om binne ' $n$ veranderende omgewing te funksioneer. Die verwagting is dat dié gemeentes meer oop sal wees vir verandering en diversiteit binne hulle onmiddellike omgewing. Die verwagting is ook dat die paradigma van sendingprojekte gemeentes sal weerhou om vanuit die onmiddelike omgewing te groei. Gemeentes is gevra om hulleself te posisioneer tussen die twee volgende pole: ' $n$ gemeente wat met sendingprojekte besig is en ' $n$ gemeente wat 'n meer missionale verstaan het (kyk Tabel 6). Tabel 6 wys dat ongeveer 'n derde van die gemeentes binne 'n sendingprojek-paradigma funksioneer, 'n volgende derde funksioneer binne 'n missionale-paradigma en die laaste derde het hulself in die middel van die kontinuum geplaas. Daar was wel na 2006 'n verskuiwing na die missionaleparadigma. Die verstaan van lidmaatskap kan binne die twee paradigmas verskil en daarom verdien dit verdere navorsing.

Gemeentes wat die fokus op instandhouding plaas, lê, ter wille van die behoud van lidmate, klem op langtermyn vaste verbintenisse van lidmate. ' $n$ Meer dinamiese en missionale verstaan van lidmaatskap kan 'n groter mate van openheid, onsekerheid en onstabiliteit in 'n gemeente te weeg bring (kyk Van Gelder 2000:67). Dit is waarskynlik dat lidmate, en 'nuwe' lidmate, wat binne 'n dinamiese konteks lewe, die ruimte van ' $n$ groter keusevryheid binne 'n gemeente sal verkies.

\section{Die verbintenis van lidmate aan die gemeente}

Die erediensbywoner-vraelys plaas die stem van die lidmaat op die tafel. 'n Keuse is uit die gegewens gemaak om te help om te verstaan hoe die verhouding tussen gemeente en lidmaat verstaan kan word. Watter rol speel die gemeente in die geloofslewe van die lidmaat, wat verwag die lidmaat van die gemeente? Dit is van die vrae wat ondersoek gaan word om te bepaal hoe hierdie lidmaatskap verhouding omskryf kan word.

Gemeentes skep ruimte vir lidmate om hulle geloof te beoefen. Daar is ' $n$ verskeidenheid aktiwiteite wat hiertoe kan help. Respondente is van mening dat eredienste en aktiwiteite van die gemeente hulle 'in 'n groot mate' $(64.0 \%$ van die respondente, Tabel 7) in hul daaglikse lewe help.

In 2010 het meer respondente as in 2006 gereken dat eredienste en die aktiwiteite van die kerk hulle in hulle daaglikse lewe help, wat daarop dui dat die rol van eredienste en gemeentelike aktiwiteite nie onderskat kan word nie. Die rol van die plaaslike gemeente word verder deur Tabel 8 toegelig. Volgens die gegewens in Tabel 8 het die meeste groei in die geloof van lidmate as gevolg van aktiwiteite van die gemeente $(40.1 \%)$ plaasgevind. Wat egter nie misgekyk moet word nie, is die rol van ander groepe en gemeentes $(11.6 \%)$ en ook die privaataktiwiteite van die lidmate (28.6\%). Die plaaslike gemeente bevredig in die meerderheid van gevalle in die geestelike behoeftes van die lidmaat (Tabel 9).

Die response van lidmate dui daarop dat die rol van die plaaslike gemeente nie misgekyk kan word nie, maar dit wys ook daarop dat ander groepe en gemeentes asook lidmate se eie en privaataktiwiteite ' $n$ rol speel. Die lidmaat verwag van die gemeente waar hy of sy inskakel om ' $n$ belangrike rol in sy of haar geloofslewe te speel en die verwagtinge speel daarom 'n bepaalde rol in die vasstelling van 'n lidmaatskapverhouding.

Sekere gemeentelike aktiwiteite en dimensies van die gemeentelike lewe speel uit die aard van die saak 'n groter

TABEL 6: Hoe funksioneer die gemeente in terme van uitreik? Merk die punt op die skaal wat die naaste aan die stelling is waarmee u saamstem.

\begin{tabular}{|c|c|c|c|c|c|c|c|}
\hline \multirow[t]{2}{*}{ Stelling 1} & \multirow[t]{2}{*}{ Jaar } & \multicolumn{5}{|c|}{$\%$} & \multirow[t]{2}{*}{ Stelling 2} \\
\hline & & 4 & 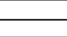 & 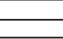 & 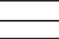 & $\longrightarrow$ & \\
\hline \multirow{2}{*}{$\begin{array}{l}\text { As een met sendingprojekte wat deel is van die } \\
\text { gewone gemeente-aktiwiteite. }\end{array}$} & 2006 & 18.6 & 17.1 & 31.4 & 21.8 & 11.1 & \multirow{2}{*}{$\begin{array}{l}\text { As 'n missionêre gemeente wat haar bestaan sien as deel } \\
\text { van God se sending na hierdie wêreld. }\end{array}$} \\
\hline & 2010 & 18.0 & 19.1 & 26.8 & 22.1 & 13.9 & \\
\hline
\end{tabular}

TABEL 7: Eredienste en gemeente aktiwiteite.

\begin{tabular}{|c|c|c|c|}
\hline \multirow{2}{*}{\multicolumn{2}{|c|}{$\begin{array}{l}\text { In watter mate help die eredienste en aktiwiteite van } \\
\text { hierdie gemeente } u \text { in u alledaagse lewe? }\end{array}$}} & \multicolumn{2}{|c|}{ Jaar } \\
\hline & & \multirow{2}{*}{$\begin{array}{c}2006(\%) \\
49\end{array}$} & \multirow{2}{*}{$\begin{array}{c}2010(\%) \\
64.0\end{array}$} \\
\hline 1. & In'n groot mate & & \\
\hline 2. & In'n mate & 40 & 27.6 \\
\hline 4. & Glad nie & 3 & 2.2 \\
\hline
\end{tabular}

TABEL 8: Geloofsgroei.

\begin{tabular}{|c|c|c|c|}
\hline \multirow{2}{*}{\multicolumn{2}{|c|}{$\begin{array}{l}\text { Hoeveel het u die afgelope jaar in u geloof gegroei? } \\
\text { (Merk net een). }\end{array}$}} & \multicolumn{2}{|c|}{ Jaar } \\
\hline & & \multirow{2}{*}{$\begin{array}{c}2006(\%) \\
1\end{array}$} & \multirow{2}{*}{$\begin{array}{c}2010(\%) \\
2.2\end{array}$} \\
\hline 1. & Nee, geen groei & & \\
\hline 2. & Min groei & 19 & 17.5 \\
\hline 3. & Baie groei, meesal as gevolg van die gemeente & 39 & 40.1 \\
\hline 4. & $\begin{array}{l}\text { Baie groei, meesal as gevolg van ander groepe en } \\
\text { gemeentes }\end{array}$ & 12 & 11.6 \\
\hline 5. & $\begin{array}{l}\text { Baie groei, meesal as gevolg van my eie privaat } \\
\text { aktiwiteite }\end{array}$ & 28 & 28.6 \\
\hline
\end{tabular}


rol as ander in 'n lidmaat se verwagtinge. In Tabel 10 word geillustreer watter aktiwiteite en dimensies vir lidmate van meerdere of mindere waarde is.

$\mathrm{Na}$ aanleiding van die gegewens in Tabel 10 kan die volgende uitgewys word:

- Die erediens en prediking (stelling 7) en die Nagmaalsviering (stelling 5) is die gemeentelike aktiwiteite wat vir lidmate van grootste waarde is. Dit is gemeenskaplike rituele en aanbiddingsaktiwiteite waaraan lidmate deelneem en daarom is dit vir hulle belangrik.

- Daar was tussen 2006 en 2010 'n belangrike verskuiwing in die verwagting van die lidmaat oor die gemeente se betrokkenheid by die groter nood van die gemeenskap (stelling 1). Dit moet saamgelees word met die missionêre bediening (wat reeds bespreek is) en ook met die klem op praktiese omgee vir mekaar in tye van nood (stelling 11). Lidmate heg al groter waarde aan die betrokkenheid van die gemeente in die gemeenskap.

Soos verwag kan word, is dit in die meerderheid gevalle NG lidmate wat tussen gemeentes migreer (Tabel 11).
Dit is opvallend dat minder NG-lidmate in 2010 van ander NG gemeentes kom as wat in 2006 die geval was (stelling 1). Daar is 'n toename in lidmate wat van ander denominasies soos ander Afrikaanse gereformeerde kerke, Presbiteriane en charismatiese kerke migreer. Dit dui waarskynlik op 'n groter openheid vir en aanvaarding van diversiteit binne die gemeente. Dit is beslis ' $n$ terrein vir verdere navorsing.

Gemeentes funksioneer binne 'n dinamies-veranderende konteks. Die antwoorde en programme van die verlede werk nie noodwendig steeds nie. In 2006 het die meeste respondente gevoel die gemeente moet by die huidige rigting hou (kyk stelling 2 van Tabel 12).

Die mening verskuif egter in 2010 na 'n klem op gemeentes wat besluit om 'n nuwe rigting in te slaan (stelling 4). Lidmate beleef ' $n$ groter openheid vir verandering en verwag waarskynlik van die gemeente om dit ook te doen. Gemeentes kan nie net aanneem dat dit die verwagting van lidmate is om nie te verander nie en sodoende geen aanpassings in die gemeentelike koers maak nie.

TABEL 9: Geestelike behoeftes.

\begin{tabular}{|c|c|c|c|}
\hline \multirow{2}{*}{\multicolumn{2}{|c|}{$\begin{array}{l}\text { Stem u saam of verskil u: 'My geestelike behoeftes word deur hierdie } \\
\text { gemeente bevredig.' }\end{array}$}} & \multicolumn{2}{|c|}{ Jaar } \\
\hline & & \multirow{2}{*}{$\begin{array}{c}2006(\%) \\
33\end{array}$} & \multirow{2}{*}{\begin{tabular}{|c|}
$2010(\%)$ \\
33.1
\end{tabular}} \\
\hline 1. & Stem beslis saam & & \\
\hline 2. & Stem saam & 47 & 48.7 \\
\hline 3. & Neutraal of onseker & 11 & 10.5 \\
\hline 4. & Stem nie saam nie & 8 & 6.5 \\
\hline 5. & Stem beslis nie saam nie & 2 & 1.2 \\
\hline
\end{tabular}

TABEL 10: Gemeentelike aspekte van waarde.

Watter van die volgende aspekte van hierdie gemeente het vir u die meeste waarde? (Merk nie meer as $\mathbf{3}$ moontlikhede nie).

\begin{tabular}{ccc} 
& Jaar & \\
\hline $\mathbf{2 0 0 6}(\boldsymbol{\%})$ & $\mathbf{2 0 1 0}(\boldsymbol{\%})$ \\
\hline 28 & 40.0 \\
13 & 15.6 \\
21 & 18.9 \\
15 & 15.1 \\
42 & 41.5 \\
10 & 6.3 \\
59 & 59.0 \\
15 & 12.6 \\
13 & 13.4 \\
7 & 11.1 \\
23 & 23.3 \\
- & 2.6 \\
3 & 3.5 \\
- & 3.2 \\
\hline
\end{tabular}

TABEL 11: Gemeentelike migrasie.

Voordat u na die gemeente gekom het, by watter gemeente uit die volgende denominasies het $u$ ingeskakel?

1. Nederduits Gereformeerde Kerk

2. Gereformeerde Kerk, Nederduitsch Hervormde Kerk of Afrikaanse Protestante Kerk

3. Presbiteriaanse, Metodiste of ander Engelse Kerk

4. Apostoliese Geloof Sending of ander charismatiese kerk

5. Rooms Katolieke Kerk

6. Ander

7. Ek was nie voorheen lidmaat van 'n gemeente nie Jaar

\begin{tabular}{cc}
\hline & Jaar \\
\hline $2006(\%)$ & $\mathbf{2 0 1 0}(\%)$ \\
\hline 89 & 81.6 \\
6 & 7.4 \\
1 & 1.7 \\
2 & 3.8 \\
0 & 0.2 \\
1 & 2.1 \\
- & 3.2 \\
\hline
\end{tabular}


Die leierskap van die gemeente en veral die predikant as leier speel ' $n$ belangrike rol in die lewe van die gemeente en die lidmaat (kyk Tabel 13).

Tabel 13 gee 'n beskrywing van wat lidmate as die rol van die predikant in die gemeente beskou. Die verwagting is dat die veranderinge en klemverskuiwings wat hierbo bespreek is, neerslag sal vind in die verwagtinge van die lidmaat ten opsigte van die rol van die predikant in die gemeente. Lidmate het 'n groeiende behoefte aan geestelike begeleiding (stelling 3) en geestelike leierskap (stelling 4) getoon. Prediking en die lei van eredienste bly die belangrikste rol van 'n predikant, hoewel minder lidmate so redeneer as wat in 2006 die geval was (stelling 1). Daar is ' $n$ skerp afname in die verwagting dat 'n predikant huisbesoek en ander besoeke moet doen (stelling 2). Daar is besliste verskuiwings in die rolverwagtinge wat lidmate ten opsigte van leierskap in die gemeente koester. Dit beïnvloed die verhouding en verbintenis tussen die lidmaat en gemeente.

Die bespreking van die empiriese data oor lidmaatskap het tendense binne die NG-kerk uitgelig. Dit dui daarop dat die verhouding lidmaat-kerk nie net in terme van 'n kwantitatiewe daling in lidmaatgetalle beskryf kan word nie. Verskeie faktore veroorsaak groei en afname en en behoort tydens 'n analise van lidmaatskaptendense verreken te word (kyk bv. Bruce et al. 2006). 'n Enkelvoudige aanname is om te beweer dat die kerk oor die afgelope twee jaar 50000 lidmate verloor het, dat die kerk op grond van 'n liniêre beraming oor 20 jaar die helfte van sy lidmate kan verloor en dat die kerk oor 'n paar dekades geen lidmate oor sou hê nie. So 'n afleiding kan om twee belangrike redes nie sonder meer gemaak word nie Eerstens is statistiese beraming oor die wisseling in getalle vanuit ' $n$ empiriese perspektief, komplekser as 'n enkele inferensie. Tweedens is lidmaatskap en die verbintenis aan 'n geloofgemeenskap vanuit ' $n$ teoretiese perspektief meer en dieperliggend as wat blote lidmaatregisterinskrywings kan impliseer.
Die verbintenis aan 'n gemeente lê op 'n dieper en meer komplekse vlak as 'n blote nominale verbintenis aan 'n gemeente. Gelowiges dink anders oor hulle verbintenis aan 'n gemeente as 20 of 30 jaar gelede (kyk Basson 2010). Die NGKerk staan voor die uitdaging om, binne 'n nuwe tydsgleuf, nuut oor die beskrywing en definiëring van lidmaatskap te dink. Die dalende lidmaattendens is nie sonder betekenis nie, want dit stel die uitdaging aan die kerk om ruimte te skep om op nuwe en kreatiewe maniere oor lidmaatskap te praat. Die tendens noodsaak 'n tweede oorweging, naamlik 'n teoretiese of teologiese refleksie.

\section{'n Raamwerk vir nuwe of veranderende verstaan van lidmaatskap}

Die betrokkenheid van individue by geloofsgemeenskappe vind binne 'n spesifieke en dinamiese konteks plaas. Veranderende kontekste stel nuwe uitdagings aan die verhouding gemeente-lidmaat en daarom behoort die verhouding van tyd tot tyd herdefinieer te word (Dreyer 2011). Osmer (2008:42) stel dit dat '[i]ndividuals now affiliate with religious communities not out of denominational loyalty, but because they believe a congregation has something to contribute to their personal spiritual quest.' Gemeentes kompeteer al meer op 'n openbare geestelike markplein waar individue hulle verhouding met die gemeente definieer in terme van persoonlike sake en behoeftes.

Die verstaan van die lidmaatskapverhouding word vloeibaarder en minder dogmaties beskryf. Heitink (2008) en De Roest $(2005,2010)$ help om na te dink oor hierdie veranderinge in die verstaan van lidmaatskap.

Heitink (2008:161-162) beskryf drie tipes kerke wat kan help om betrokkenheid van gelowiges by 'n geloofsgemeenskap te beskryf. Die volkskerk (of publieke/staatskerk) en die

TABEL 12: Gemeentelike rigting.

\begin{tabular}{|c|c|c|c|}
\hline \multirow{2}{*}{\multicolumn{2}{|c|}{$\begin{array}{l}\text { Watter een van die onderstaande stellings beskryf, na u mening, die toekomstige rigting wat die gemeente in die toekoms } \\
\text { moet betree, die beste? }\end{array}$}} & \multicolumn{2}{|c|}{ Jaar } \\
\hline & & \multirow{2}{*}{$\frac{2006(\%)}{5}$} & \multirow{2}{*}{ 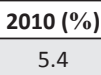 } \\
\hline 1. & Ons moet terug beweeg na hoe ons dinge in die verlede gedoen het & & \\
\hline 2. & Ons moet gelowig hou by die huidige rigting & 48 & 23.0 \\
\hline 3. & Ons is besig om te besluit oor' $n$ nuwe rigting & 9 & 12.2 \\
\hline 4. & Ons beweeg nou in'n nuwe rigting & 18 & 32.6 \\
\hline 5. & Ons moet herbesin oor die rigting waarin ons beweeg & 11 & 11.2 \\
\hline 6. & Ons toekoms is onseker en twyfelagtig & 3 & 2.9 \\
\hline 7. & Weet nie & 5 & 12.6 \\
\hline
\end{tabular}

TABEL 13: Rol van die predikant.

Wat is belangrikste rol wat' $n$ predikant van dié gemeente moet vervul? (Merk nie meer as 3 nie).

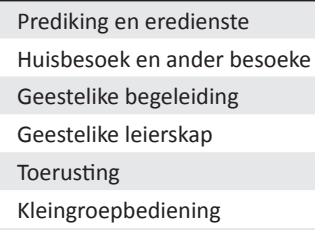

\begin{tabular}{cc}
\multicolumn{2}{c}{ Jaar } \\
\hline $\mathbf{2 0 0 6}(\boldsymbol{\%})$ & $\mathbf{2 0 1 0} \mathbf{( \% )}$ \\
\hline 82 & 72.9 \\
42 & 32.1 \\
56 & 59.4 \\
39 & 41.7 \\
14 & 11.2 \\
5 & 3.4 \\
11 & 11.1 \\
\hline
\end{tabular}


samelewing oorvleuel. Kerk en samelewing is dieselfde en soveel moontlik lede van die samelewing is ook lidmate van die volkskerk. Die tweede tipe is die vrye kerk. In hierdie geval besluit die lede van die gemeenskap self wie waar inskakel. Die mondigheid van die gemeente en die keuse van die lidmate staan voorop. Derdens verwys hy na die mistieke of charismatiese kerk. In hierdie geval word die klem op die individu se persoonlike keuse waar om in te skakel, geplaas. Binne die tipologie van kerkwees wissel die beskrywing van lidmaatskap. Dit is veral verandering in die samelewing wat ' $n$ herbeskrywing noodsaak. Heitink (2008:175-181) kies 'n groter openheid in die omskrywing van lidmaatskap. Lidmaatskap kan in terme van konsentriese sirkels verstaan word. Persone kan, in hulle verhouding met die lewende Here, nader beweeg of verder wegstaan. Iemand staan en kyk, kom nader, word deel van die binnekring of loop later weer weg. Hy sien kenmerke van die bewegings by die Johanneïse geloofsgemeenskap.

De Roest (2008:41-53) verkies om drie metafore te gebruik om die gemeenskapsvorming binne'n gemeente te beskryf. Die kerk as vangnet vereis totale betrokkenheid van lidmate. Programme soos die van Rick Warren (Purpose driven life) val byvoorbeeld binne hierdie beskrywing. Die doel van die gemeente is om soveel 'visse' as moontlik vir altyd in die vangnet te kry. Die strategie is om mense te bereik, binne te nooi, te boei en aan die gemeente te bind. Die kerk as herberg skep ruimte vir 'n geleidelike en geskakeerde betrokkenheid. Die eredienste word gekenmerk aan 'n gasvrye liturgie wat mense binnenooi om te kom kyk. Daar is ' $n$ openheid en die geleentheid tot vrywillige deelname. Die kernspan (leierskap) het 'n hoë vlak van betrokkenheid, maar individue het 'n vryer keuse tot betrokkenheid by die 'gastehuis'. Die kerk as tempel laat ruimte vir insidentele betrokkenheid, want dit kan na behoefte besoek word. Dit gebeur gewoonlik tydens bepaalde rituele, veral tydens belangrike gebeure in ' $n$ persoon se lewe, byvoorbeeld by ' $n$ doopgeleentheid of tydens troues en begrafnisse. In 'n latere werk stel de Roest (2010) die metafoor van 'n huis voor. Hy sien 'huis' as 'n dinamiese konsep wat ruimte laat vir '... een grote variatie aan kerkvormen en kerkplekken, met verschillende mogenlijkheden tot partisipatie' (De Roest 2010:40). Hy verstaan dit glad nie as 'n eksklusiewe konsep nie, maar as deelname op verskeie vlakke.

Hierdie verskillende metafore help om ruimte te skep om nie in terme van lidmaatskap in vaste kategorieë te dink nie. Die moontlikheid word geskep dat daar groter vryheid vir individuele keuses oor die graad van betrokkenheid sal wees. Geloof en 'n verbintenis aan 'n geloofsgemeenskap loop nie altyd hand aan hand nie (Davie 2007:274). Persoonlike voorkeure en die aantreklikheid van gemeentes speel in die verband 'n belangrike rol (die bespreking van die empiriese gegewens het dit duidelik gemaak). Gemeentes en lidmate wat op 'n vrye markplein lewe, is aan die kragte van die mark en bemarkingsstrategieë blootgestel (Britz \& Müller 2003:9-10). Die keuse van 'n gemeente kan deur leefstylkeuses beïnvloed word en die supermark se bemarking en die gemeente se aanloklikheid kom op dieselfde vlak tereg. As jou leefstyl belangrik is, kan jy van supermark verander, waarom sou dit nie vir 'n gemeente geld nie? As dit tyd is om 'n bepaalde toestel op te gradeer, word die verskillende keuses aan die verbruiker voorgehou om hom of haar in staat te stel om 'n goeie keuse te maak. Lidmaatskap is ingevolge hierdie denkwyse 'n verbruikerskommoditeit en word deur 'n verbruikerskultuur beïnvloed omdat deelname 'n persoonlike keuse word (Davie 2007:281).

In 'n onderhoud met die Kerkbode van 18 Januarie 2013 antwoord die historikus Hermann Giliomee die volgende oor sy verbintenis aan die kerk: "n Porterville-seun, gedoop en aangeneem in die NG Kerk, tans 'n passiewe lidmaat.' Lidmaatskap veronderstel nie noodwendig 'n volledige verbintenis aan 'n enkele gemeente nie. Kan kerklike lidmaatskap net verstaan word as 'n dogmatiese belydenis gekoppel aan 'n geografiese adres binne die gemeentegrense? Die ontwikkeling van vloeibaarheid in die moderne samelewing maak vaste kategorieë en 'n rigiede sistematisering moeilik en stel die uitdaging om op nuwe en kreatiewe wyses daaroor te dink om te kategoriseer (Bauman 2007:33; Joubert 2013:116-120). Die kerk en gemeentes ontsnap nie die uitdaging nie en daarom behoort konsepte soos lidmaatskap en verbintenis (koinonia) binne 'n veranderende kulturele omgewing herbedink te word (De Groot 2009:369-370). Ruimte behoort geskep te word om in minder rigiede terme en dalk in meer vloeibare terme oor lidmaatskap te praat (Erwich 2012:6). Kenmerkend van so 'n vloeibare verstaan is dat lidmaatskap as 'n dinamiese verhouding verstaan word, wat induktief deur die gelowige omskryf word met die klem op die kwaliteit van die verhouding met die drie-enige God en sy gemeente.

'n Meer vloeibare verstaan van lidmaatskap het bepaalde implikasies en die volgende kan onder andere uitgewys word:

- Vir lidmate beteken dit, binne die ruimte van 'n verbruikerskultuur, dat bepaalde keuses uitgeoefen word, byvoorbeeld om by een gemeente se kleingroepe in te skakel en by 'n ander se projekte of eredienste. Daar is wisselende vlakke van intensiteit in die verhouding en ruimte vir groei, maar daar is ook vir lidmate geleentheid om terug te staan en te worstel of om vir 'n tyd lank weg van 'n geloofsgemeenskap te stap. Die gevaar wat individualisme en die privatisering van godsdiens speel, moet nie gedurende die proses onderskat word nie.

- Vir gemeentes hou 'n vloeibare verstaan van lidmaatskap 'n verskeidenheid implikasies in. Gemeentes kan nie net op 'n bemarkingstrategieë fokus om lidmate te lok nie. Die klem word ook op die rol van die predikant en gemeentelike leierskap om lidmate aan 'n geloofgemeenskap te verbind, geplaas. Jaarlikse gesprekke kan oor lidmate se verbintenis aan die gemeente plaasvind (Heitink 2008:184-189). Gemeentes word opnuut uitgedaag om die verbintenis tussen gelowige en gemeentes te herbeskryf en nuwe ekklesiologieë te ontwikkel (Niemandt 2012). 


\section{'n Slotopmerking}

Verskeie hoofstroom denominasies ondervind weens 'n verskeidenheid redes ' $n$ daling in lidmaatgetalle. Die verhouding lidmaat-gemeente kom tereg binne 'n dinamies veranderende konteks wat nie meer in enkelvoudige terme beskryf kan word nie. In die verband stel Joubert (2013):

Amidst the various forms of complexity that mark our world, better integrative spiritual skills, based on inner, shared experiences of the metanoetic reality of God's kingdom, provide creative new opportunities for the church to presence herself in a fluid world as a community of individuals who loves God and others in magnetic ways. (bl. 127)

Lidmaatskap behoort as 'n vloeibare en veranderlike beskrywing van die verhouding lidmaat-gemeente beskou te word. Die uitdaging is om 'n nuwe ekklesiologie met nuwe terme en metafore te ontwikkel, want agter die syfers is gelowiges, gemeentes en die kerk.

\section{Erkenning \\ Mededingende belange}

Die outeur verklaar dat hy geen finansiële of persoonlike verbintenis het met enige party wat hom nadelig kon beïnvloed in die skryf van hierdie artikel nie.

\section{Literatuurverwysings}

Basson, E.F., 2010, 'Die assimilasie van lidmate in die plaaslike geloofsgemeenskap, HTS Teologiese Studies/Theological Studies 66(2), 1-7. http://dx.doi.org/10.4102/ hts.v66i2.827

Bauman, Z., 2007, 'On being light and Iquid', in A. Elliot (ed.), The contemporary Bauman, 29-33, Routledge, London and New York.

Britz, J. \& Müller, J.C., 2003, "n Bemarkende en bemarkbare kerk,' Practical Theology in $S A, 18(2), 1-12$.

Bruce, D., Woolever, C., Wulff, K. \& Smith-Williams, E.,2006, 'Fast-growing churches: what distinguishes them from others?' Journal of Beliefs \& Values 27(1), 111-126. http://dx.doi.org/10.1080/13617670600594582

Davie, G., 2007, 'Religion in Europe in the 21 century: The factors to take into account,' European Journal of Sociology 47(2), 271-296. http://dx.doi.org/10.1017/ S0003975606000099

De Groot, C.N., 2009, 'Theological issues in fluid ways of being church,' in W. Grab \& L. Charbonnier, Secularization theories, religious identity and practical theology, 364-371, Lit Verlag, Zurich.(International Practical Theology, vol. 7).
De Klerk, B.J. \& Van Helden, P., 2011, 'Oorsake van kerkkrimping binne die tradisioneel Afrikaanssprekende gereformeerde kerke in Suid-Afrika,' Verbum et Ecclesia 32(1), 18-20. http://dx.doi.org/10.4102/ve.v29i2.47

De Roest, H., 2005, En de wind steekt op! Kleine ecclesiologie van de hoop, Meinema, Zoetermeer

De Roest, H, 2010, Een huis voor de ziel. Gedachten over de kerk voor binne en buiten Meinema, Zoetermeer.

Dreyer, T.F.J., 2003, 'Statistieke vertel'n storie : 'n Visie vir die Hervormde Kerk op pad na 2010,' HTS Teologiese Studies/Theological Studies 59(4), 1045-1062. http:// dx.doi.org/10.4102/hts.v59i4.685

Dreyer, W.A., 2011, "n Multidissiplinêre benadering tot Praktiese Ekklesiologie,' HTS Teologiese Studies/Theological Studies 67(2), 1-10. http://dx.doi.org/10.4102/ hts.v67i2.1088

Erasmus, J.C. \& Hendriks, H.J., 2005, 'Religion in South Africa: The 2001 population census data,' Journal of Theology for Southern Africa, 121(March), 88-111.

Erwich, R., 2012, 'The impact of the liquid church discourse in Dutch Evangelical Churches: A practical theological analysis', in C. Van der kooi, Van StaalduineSulman, A.W. Zwiep, Evangelical Theology in Transition, pp. 71-85, VU University Press, Amsterdam.

Ganzevoort, R.R., 2009, 'Forks in the road when tracing the sacred. Practical theology as hermeneutics of lived religion,' Presidential address to the 9th conference of the International Academy of Practical Theology, Chicago, United States of America, August 03, 2009, viewed 24 April 2010, from http://www.ruardganzevoort.nl/ pdf/2009 Presidential.pdf

Gereformeerde Kerke van Suid-Afrika (GKSA), 2012, 'Handelinge van die tweede Algemene Sinode van die Gereformeerde Kerk in Suid Afrika', gehou te Potchefstroom op 04 Januarie 2012 en volgende dae. 'Hele geslag wit mense verlaat SA', Rapport, 24 September, 2006

Heitink, G, 1993, Pracktische Teologie, geschiedenis-theorie-handelingsvelde, Uitgeverij Kok, Kampen.

Heitink, G., 2008, Een kerk met kakrakter. Tyd voor heroriëntatie, Tweede druk, Uitgeverij Kok, Kampen.

Joubert, S., 2013, 'Not by order, nor by dialogue: the metanoetic presence of the kingdom of God in a fluid new world and church,' Acta Theologica 33(1), 114-134.

Lugo, L. \& Cooperman, A., 2010, Tolerance and tention: Islam and Christianity in SubSaharan Africa, Washington.

Nederduitse Gereformeerde Kerk, 1994, Handelinge van die Algemene Sinode van die Nederduitse Gereformeerde Kerk, Pretoria.

Nederduitsch Hervormde Kerk van Afrika (NHKA), 2010, Notule van die Algemene Kerkvergadering, September 2010, Pretoria. Kerkargief, Pretoria.

'NGK-lidmate 20000 minder in een jaar', Rapport, 19 Februarie, 2012.

Niemandt, C.J.P., 2012, 'Trends in missional ecclesiology,' HTS Teologiese Studies/ Theological Studies 68(1), 1-10. http://dx.doi.org/10.4102/hts.v68i1.1198

Osmer, R., 2008, Practical theology, an introduction, W.B. Eerdmans, Grand Rapids, MI.

Roozen, D.A., 2008, American Congregations 2008, Hartford Insttute for Religion Research, Hartford, CT.

Schoeman, W.J., 2011, 'Kerkspieël - 'n kritiese bestekopname,' Nederduits Gereformeerde Teologiese Tydskrif, 472-488.

Shahid, R. \& Zuettel, I., 2012, Global index of religion and atheism, n.p., Zurich.

South African Institute for Race Relations, 2007, Fast Facts, SAIRR.

Van Gelder, C., 2000, The essence of the church. A community created by the Spirit, Baker Books, Grand Rapids, MI.

Woolever, C. \& Bruce, D., 2004, Beyond the ordinary: Ten strengths of U.S. congregations, Westminster JohnKnox Press, Louisville, KY. 